\title{
A NOTE ON 2 CORINTHIANS I:9
}

\author{
By c. J. HEMER
}

The article by Dr Murray Harris in the last issue of the Tyndale Bulletin $^{1}$ raises incidentally the old problem of the nature of the

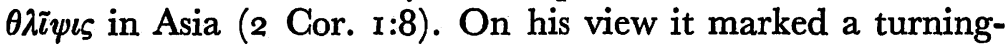
point in Paul's perspective on death and resurrection. Without entering here on speculation about the circumstances or on discussion of the problems of Pauline thought which he has treated so ably, I suggest that a verbal point in verse 9 may shed light on his contention that Paul's experience was one of mortally critical import.

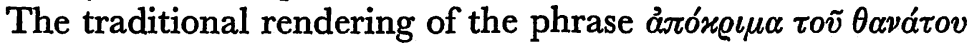
is 'sentence of death' (so AV, RVmg., RSV, NEB). ${ }^{2}$ The RV text alone offers the literal, if obscure, 'answer of death' ${ }^{3}$ The usual version goes back to Chrysostom and Theodoret, and is supported by a gloss of Hesychius. ${ }^{4}$

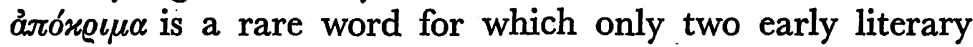
parallels are cited, but which occurs sparingly in inscriptions, including some close in time and place to the provenance of our text. They are sufficient to show that the supposed sense here is unparalleled. There is no ground in contemporary usage for seeing a judicial metaphor here. The comments of Ditten-

1 M. J. Harris, Tyndale Bulletin 22 (1971) 57.

2 So also Moffatt. Goodspeed paraphrases: 'I felt in my heart that the end must be death'. $C f$. J. B. Phillips.

There has apparently been little discussion of the difficulty of this rendering. G. S. Duncan, for instance, in St. Paul's Ephesian Ministry, Hodder, London (1929) I3I ff., I94 ff., seems to assume the traditional view as a datum for urging an unrecorded imprisonment which he locates conjecturally at Laodicea. See however Moulton and Milligan in The Expositor 7 th ser. 6 (1908) 187 and in The Vocabulary of the Greek Testament 64; A. Deissmann, Bible Studies, T. \& T. Clark, Edinburgh (rgor) 257 and $c f$. $L A E$ 337n.

The usage of ámoкpivw and other cognates gives no support to the meaning 'sentence'.

${ }^{8} C f$., however, Vulg. responsum mortis.

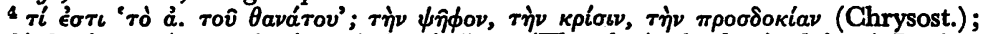

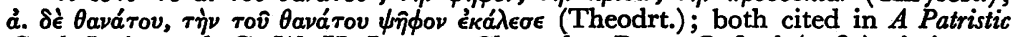
Greek Lexicon, ed. G. W. H. Lampe, Clarendon Press, Oxford (1961); ámórepıra.

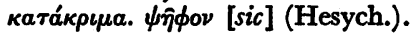


berger, $M M$, and Deissmann all point in a different direction. ${ }^{5}$

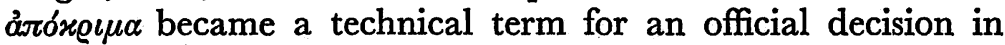
answer to the petition of an embassy.

The surviving parallels illustrate the point clearly:

(a) The earliest reference is probably that in Polybius, $12.26^{b} .1$, who says that the representatives of the Greeks in

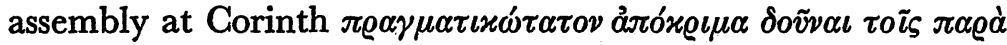

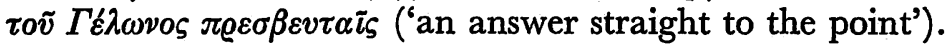

(b) A lengthy but fragmentary series of documents of Pergamum, dealing with a dispute between Pitane and Mytilene and dating from the last years of the Attalid kingdom, mentions

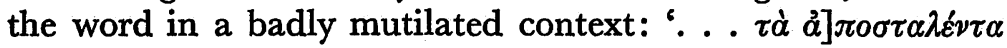

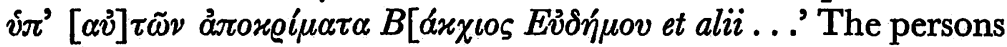
listed are shown elsewhere in the inscription to have been the ambassadors of Pergamum. ${ }^{6}$

(c) A decree of Acraephiae in Boeotia (AD 37) honours one

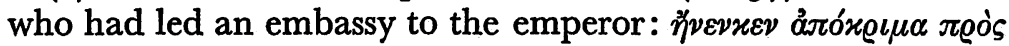

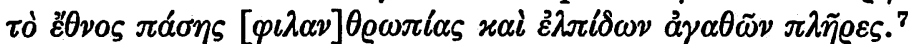

(d) A fragment from Rhodes (AD $5 \mathrm{I}$ ) uses the same formula. The broader context is evidently similar: '. . .] $\tau \dot{\alpha} \varepsilon v \dot{u} x \tau \alpha \iota{ }^{\prime} \tau \alpha \tau \alpha$

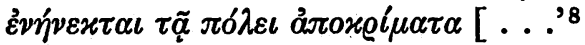

(e) A decree of Cos (AD 54) honouring the imperial physician G. Stertinius Xenophon records that he also held the post $\dot{\varepsilon} \pi i$

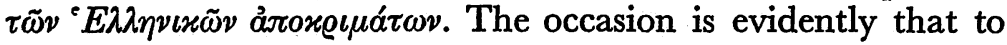
which Tacitus refers (Ann. I2.6I): with the man's secretarial office compare $(h)$ and $(j)$ below. ${ }^{9}$

(f) The only other early literary reference is itself contained in the citation of a decree of Julius Caesar in favour of the Jews (Jos. Ant. I4. 10.6.210). The privileges accorded Hyrcanus,

5 Dittenberger on (e) and (h) below; $M M$ and Deissmann, locc cit.

- Orientis Graeci Inscriptiones Selectae, ed. W. Dittenberger, Hirzel, Leipzig (1903-1905) 335.94-96. The restoration of the list of names is guaranteed by lines $4-6$ and $48-50$. The verb is not preserved in the present context. The lettering is assigned to the mid-second century BC; the restoration of $[\tau] \circ \hat{v} \beta a \sigma \iota\left[\lambda \epsilon^{\prime}\right] \omega s$ (line 9o) in the heading of the Pergamene decree dates the documents before 133 BC.

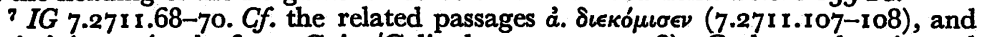

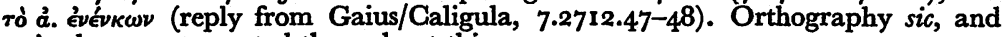
so in documents quoted throughout this paper.

8 IG 12.1.2.4. The grant of privileges to Rhodes at this time is well attested; see Suet. Claud. 25.3; Nero 7.2; Tac. Ann. 12.58, dating the event to AD 53.

- Sylloge Inscriptionum Graecarum, ed. W. Dittenberger, Hirzel, Leipzig, ${ }^{3}\left(1915^{-1924)} 804.5={ }^{2}(1898-1901) 386.5\right.$. Tacitus attributes the benefits bestowed on Cos to the high favour this Xenophon enjoyed with Claudius. For the same man's alleged complicity in the poisoning of his imperial patron shortly afterwards see Tac. Ann. 12.67. 
his children, and the ambassadors sent by him conclude with

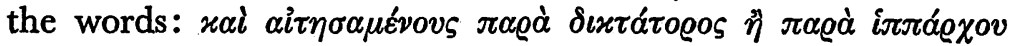

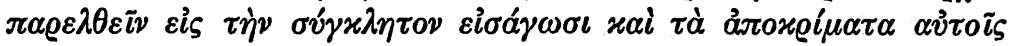

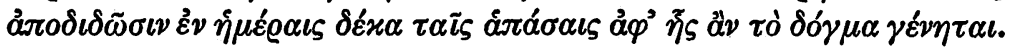

(g) A legal papyrus text of the second century AD cites part of an ảंóx $\theta \varepsilon o \tilde{v}^{\circ} A \delta \varrho \iota \alpha v o \tilde{v}$. The history of the case is obscure and the force

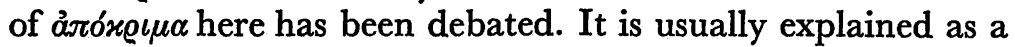
'rescript', though Wilcken compares the áropá $\sigma \varepsilon \iota \varsigma$ of Trajan and Hadrian later in the same text. That term is more suggestive of the 'award' of an arbitrator. ${ }^{10}$

(h) An inscription of Miletus, undated but of about the second century $A D$, honours another person eminent in the public service $\lambda \alpha \beta \dot{\omega} \nu[\mu]$ óvos $\delta \mu \sigma \tilde{v} \pi[i \sigma] \tau \iota \nu \dot{\varepsilon} \pi \iota \sigma \tau o[\lambda \tilde{\omega}] \nu, \dot{\alpha} \pi 0 \varkappa \varrho[\iota \mu]-$

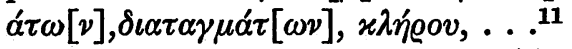

(j) Suidas, on Dionysius of Alexandria, the librarian there in the later first century $\mathrm{AD}$, records of him also that $\dot{\varepsilon} \pi \hat{i} \tau \tilde{\omega} \nu$

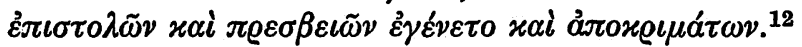

These documents, when set carefully in context, give an interesting picture. The word á $\pi o^{\prime} \varkappa \iota \mu \alpha$ was evidently current in the official language of the early Empire. Two of the four texts from the territory of proconsular Asia (which included the islands of Rhodes and Cos) ${ }^{13}$ are datable as within five years previous to the writing of 2 Corinthians $I: 9 .{ }^{14}$ The meaning is clear in several cases from the setting. The connection with

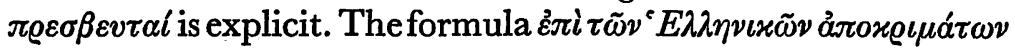
and its variants are analogous with the titles of the celebrated

10 Tebtunis Papyri, ed. B. P. Grenfell, A. S. Hunt, et al., University of California, London and New York (1902) 2.286.I. Against the common view here see U. Wilcken, 'Zu den Kaiserrescripten', Hermes 55 (1920) 32n. For ảmó

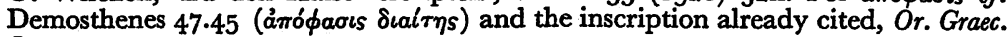
Inscr. 335.72.

11 Or. Graec. Inscr. 494.1 7-19. The man evidently held these responsibilities under

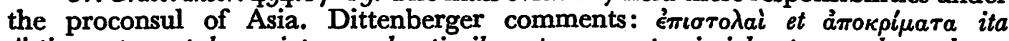
distinguuntur, ut haec sint quae legationibus, per quas provinciales proconsulem adeunt, respondentur, illae litterae quas ipse ad imperatorem, senatum, civitates procuratoresque dat;

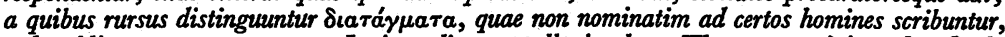

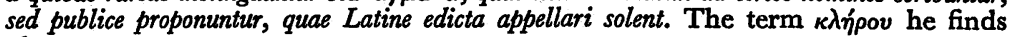
obscure.

12 Suidas, $\Delta \iota 0 v u ́ \sigma c o s$ 'A $A \epsilon \xi a v \delta \rho \in u ́ s$.

18 For the provincial limits among the Aegean islands see Ptolemy, 5.2.1, 28-32 (2nd century $\mathrm{AD}$ ).

14 On any view of the unity of the letter there is no great lapse of time involved in the unfolding of the Corinthian crisis and its correspondence. The passage will not be later than AD 56 . 
chief secretaries introduced by Glaudius. The $\dot{\varepsilon} \pi i \tau \tilde{\omega} \nu \dot{\varepsilon} \pi \iota \sigma \tau 0 \lambda \tilde{\omega} \nu$ (Plutarch, Otho $9.3 ; c f .(\mathrm{h})$ and $(\mathrm{j})$ here) was in Latin the $a b$ epistulis (Suet. Claud. 28). This Xenophon of Cos was evidently head of another department of the new imperial civil service. Perhaps his appointment gives us the Greek term corresponding to the Latin a libellis (Suet. Dom. I4), the secretary for petitions. ${ }^{15}$

The only passage which might favour a different nuance is the papyrus text $(\mathrm{g})$. But even if we understand that to refer to a 'rescript', the essential principle holds good. A 'rescript' was in essence an answer, an authoritative ruling on a question submitted.

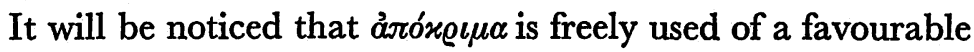
verdict. Indeed, it was the success of a mission which prompted a city to perpetuate its ambassadors' names on stone.

I suggest that the usage of 2 Corinthians $I: 9$ is not unique at all, but to be explained in terms which were current. The metaphor is not judicial.

The situation is understandable in the light of a close reading of the whole context of 2 Corinthians $I: 3-1$, which I take to have been moulded by the experience of verse 8 . In the five preceding verses $\theta \lambda \tilde{\imath} \psi \iota$ and cognates occur three times, $\pi \dot{\alpha} \theta \eta \mu \alpha$ and cognates four times, and $\pi \alpha \varrho \alpha ́ x \lambda \eta \sigma \iota \varsigma$ and cognates no fewer than ten times.

A reconstruction might be possible somewhat on the following lines. Paul had in earlier days expected to survive to the Parousia (I Thes. 4:I 5, I 7). The language of 2 Corinthians 5, whatever else it may imply, points at least to a difference of personal perspective. The time of the change may be plausibly associated with the drastic experience of 2 Corinthians $\mathrm{I}: 8 \mathrm{ff}$., of whose nature the Corinthians already knew. In his extremity Paul had 'petitioned' God about the outcome. The 'verdict' was death. ${ }^{16}$ Yet with the answer Paul was given a rich assur-

15 One may speculate that the contemporary influence of Xenophon and the favours bestowed on Asia through his agency brought to the popular notice the previously obscure term ámókpıнa in the title of the secretaryship which enabled him to deal with the granting of petitions.

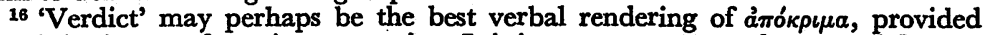
that it is given no forensic connotation. It is important to stress the neutral flavour of the word. In Paul's case the 'verdict' could equally have been 'life', but it was not God's pleasure to grant that petition.

We cannot dogmatize about the circumstances. It may well have been that a critical experience of the closeness of physical death occasioned the prayer and a consequent assurance of and resignation to a new understanding of the divine 
ance and comfort that he might in turn be enabled to mediate assurance and comfort to others $(\mathrm{r}: 4-6)$. No man could now say that he was privileged to be exempt from death until the Lord came, and was presuming to teach less favoured Christians to face a hurdle he would never meet. He was to share that experience too ( $c f . \mathrm{I}: 7)$.

With this conception of prayer as petition and verdict we may compare closely 2 Corinthians I 2:8-9. Thrice Paul besought the Lord to remove the ' $\sigma x o$ ' $\lambda \circ \psi$ in his flesh': the answer was a richer endowment of strength to overcome his weakness, though the oxódoy was not removed.

purpose for a continuing present ministry terminating in death before the Parousia. We cannot however follow $G$. $H$. Dodd in his speculation that the experience amounted to 'a sort of second conversion' (BFRL I7 (1933) 104). Dodd views the case from a quite different perspective and his idea depends on the questionable

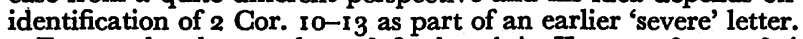

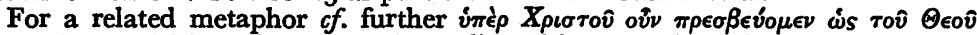

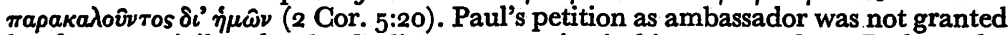
but he was privileged to be God's representative in his turn to others. Perhaps the thought here is rather different and the parallel not to be pressed, but there is at least some confirmation of the presence of this embassy theme in Paul's mind in the writing of 2 Corinthians. 